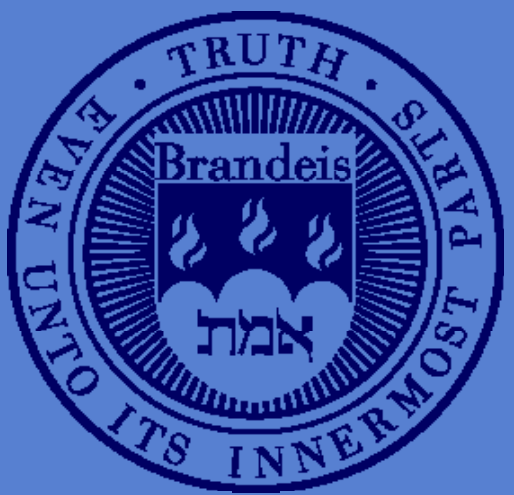

Higher Education Policies and Overeducation in Turkey

Nader Habibi, Economics Department, Brandeis University 


\section{Higher Education Policies and Overeducation in Turkey ${ }^{1}$ \\ Nader Habibi ${ }^{2}$ \\ March 2015}

\section{Introduction:}

On October 15, 2015 the President of Istanbul University, Professor Mahmut Ak, shocked the attendants in the annual ceremony for the start of the 2015-16 academic year by announcing that student enrollments for current academic year have been reduced ${ }^{1}$. This news came as a surprise to the entire academic community in Turkey. He further explained that this decision was motivated by the poor job market conditions for university graduates. The difficult labor market for university graduates is not an unnoticed issue in itself but the unemployment rate for university graduates has recently reached unprecedented levels that Turkey has never experienced before. Turkey is one of the few developed countries in which unemployment rate for workers with university degrees is higher than less educated workers.

The 2015 employment statistics for Turkey confirms Professor Ak's concern. The July 2015 statistics that were released in October show that university graduates accounted for $24 \%$ of the unemployed workers in July 2015 while the same ratio in April 2014 was only $18 \%{ }^{2}$. Concern about this issue was also acknowledged by the founder and chairman of the board of Trustees of Gedik University, Hulya Gedik, in October 2015: "There are more than 200 universities in operation. ... However, graduation doesn't guarantee getting a job. There are one million jobless university graduates [in Turkey]" 3 . This bad employment news comes at a time when a record large cohort of Turkish university students are expected to enter the labor market in the next two years. At the same time the recent political turmoil and ethnic violence is taking a toll on Turkish economy and its capacity to generate new jobs.

In this policy report we analyze the causes and consequences of the emerging employment crisis of university graduates in Turkey. Our analysis has three objectives: 1) to offer an overview of the latest developments in quantitative growth of enrollment in higher education institutions and employment status of university graduates in Turkey, 2) To analyze the policies and institutions that have led to this rapid rise of university graduates and, 3) to assess the possible responses of policy makers and households to this crisis.

In light of the fact that a large amount of public and private resources are spent on higher education, the lack of sufficient economic opportunities for university graduates represents a waste of valuable resources that could have been invested elsewhere. The frustration of millions of educated unemployed youth is also a potential source of political and social instability.

The significance of this analysis extents beyond Turkey and is relevant for other Middle Eastern economies as well. Similar to Turkey, many countries in the region,

1 While conducting this research project I have partially benefited from a grant by the Hollings Center for International Dialogue.

${ }^{2}$ Crown Center for Middle East Studies and Department of Economics, Brandeis University, nhabibi@brandeis.edu 
such as Egypt, Saudi Arabia, and Iran, have seen a sharp increase in the number of students in tertiary education institutions in recent years. Consequently they are also struggling with high rates of unemployment and underemployment among university graduates.

\section{A Statistical Overview:}

Turkey has experienced a sharp growth in the total number of students enrolled in various levels of higher education in the past two decade. Most of this growth has been realized after 2005. As shown in chart 1 total student enrolment in institutions of higher education was 1.22 million in 1995 . It rose by $88 \%$ to 2.3 million in 2005 . This sharp increase was accompanied by an even stronger demand for university education. The AKP government responded to this strong demand by introducing a comprehensive higher education strategy in 2007, which called for increasing student enrolment by expansion of both public and private universities ${ }^{4}$.

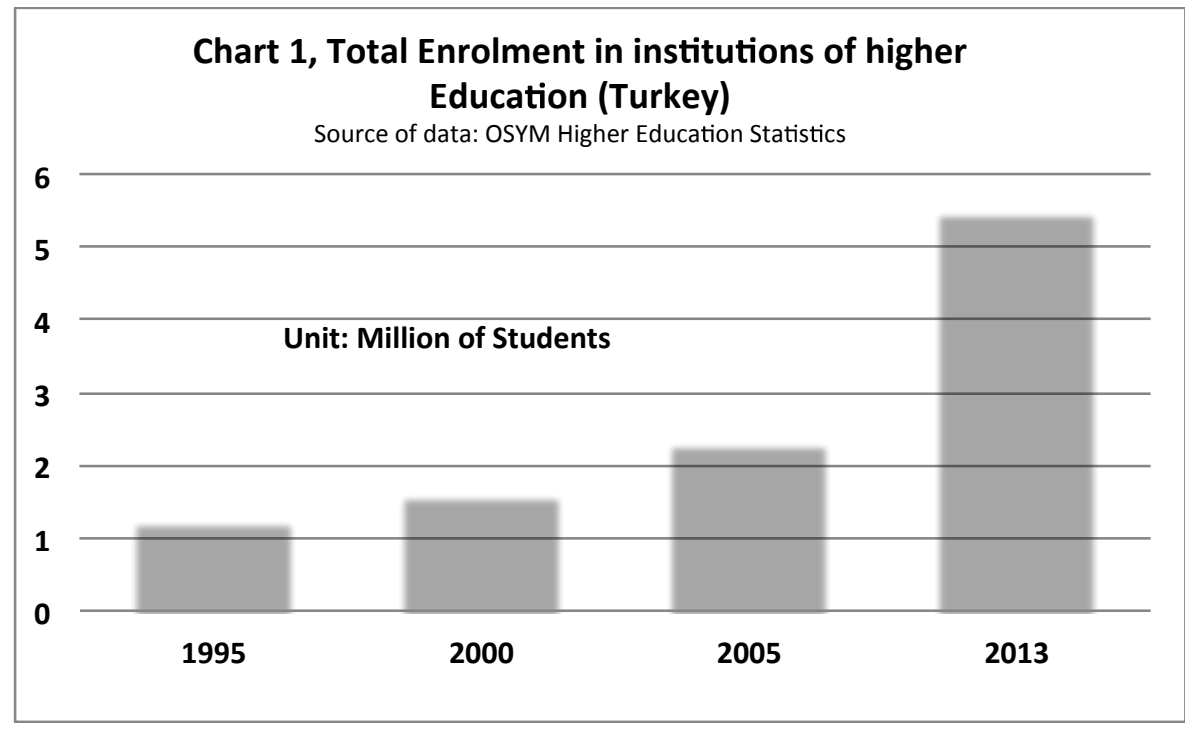

During 2005-2013, enrolment rose by $138 \%$ to a record 5.47 million students in 2013-14 academic year. While a percentage of university students leave school before graduation, the rising enrollment during past two decades has resulted in a sharp increase in number of young men and women with university degrees. As shown in Chart 2, in the 20-29 years-old age group, the percentage that hold a university degree has increased from $6.9 \%$ in 1995 to $24 \%$ in 2012. This figure is expected to increase even further in 2016 and 2017 as the large cohorts of current university students will graduate and enter the labor force ${ }^{5}$. 


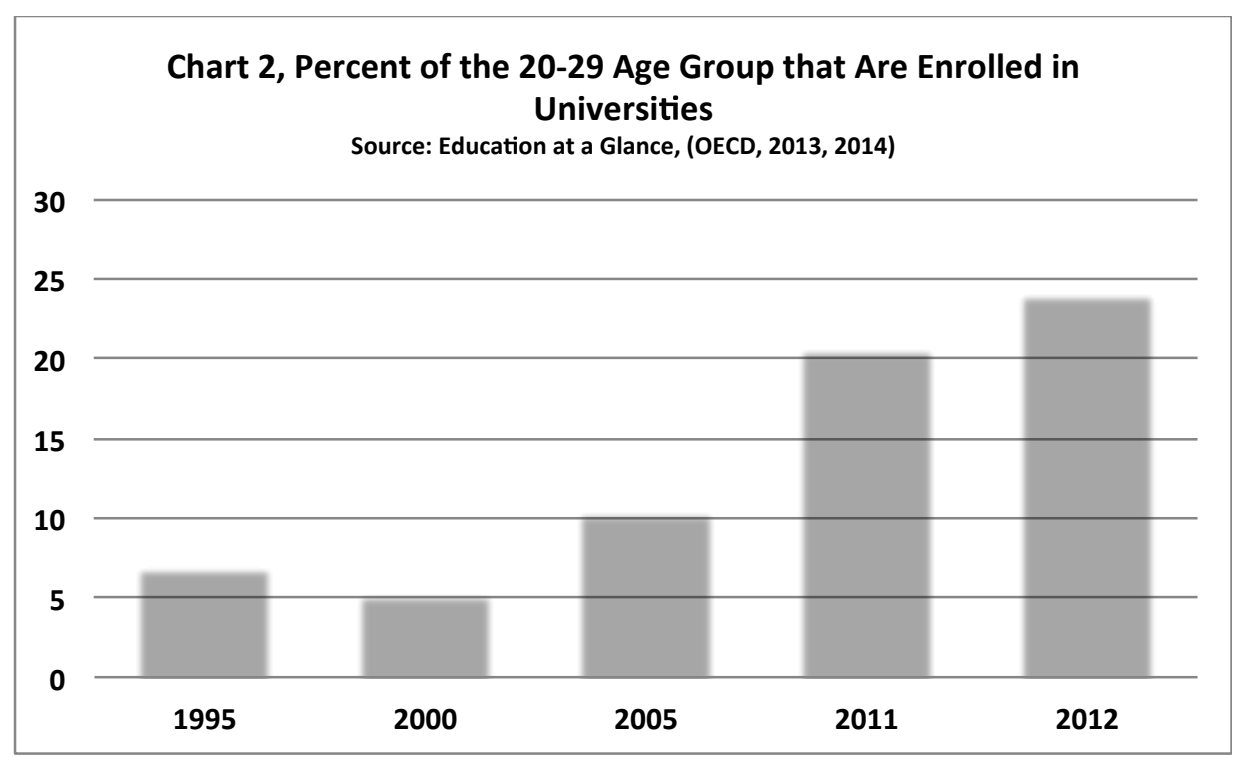

As mentioned in the introduction, the entry of large numbers of university graduates into Turkey's labor market in recent years has outpaced the demand for skilled jobs. This imbalance has not only resulted in high unemployment rates for degree holders, but it has also led to significant increases in cases of underemployment. A growing number of university graduates that are not able to fined skilled jobs are accepting semi-skilled and unskilled jobs, which do not require university degrees. Up until recently acceptance of unskilled jobs was considered a significant loss of social status for university students and many preferred to remain unemployed instead of accepting such positions. It appears that with the growing rates of unemployment among university graduates this attitude is slowly changing.

We can see in table one that between 2004 and 2014 the percent of Turkish workers with university degrees in semi-skilled and low-skill occupations has steadily increased. Among these occupations the clerical and sales jobs were traditionally favored by unemployed college graduates and we see that the share of workers with college degrees has increased from 11\% in 2004 to $20 \%$ in 2014 . The share of university graduates among workers in other low-skill jobs is small but we observe that this share has increased even faster in these categories. Among plant and machine operators (category 8) for example, the ratio has increased by $158 \%$. 
Table 1. Turkey: Percent of Workers in Semi-skilled and Unskilled Occupations that Hold a University

\begin{tabular}{|c|c|c|c|c|c|c|c|}
\hline \multicolumn{8}{|c|}{ Degree } \\
\hline ISCO Job Category & 2004 & 2006 & 2008 & 2010 & $2012^{*}$ & 2013 & 2014 \\
\hline 4) Clerical Support Workers & $23 \%$ & $26 \%$ & $30 \%$ & $32 \%$ & $39 \%$ & $40 \%$ & $41 \%$ \\
\hline 5) Service and Sales Workers & $5 \%$ & $7 \%$ & $8 \%$ & $11 \%$ & $12 \%$ & $13 \%$ & $12 \%$ \\
\hline Categories $4+5$ & $11 \%$ & $14 \%$ & $16 \%$ & $18 \%$ & $19 \%$ & $20 \%$ & $20 \%$ \\
\hline 6-Skilled agricultural, forestry and fishery workers & $0.6 \%$ & $0.9 \%$ & $0.9 \%$ & $1.0 \%$ & $1.1 \%$ & $1.2 \%$ & $1.5 \%$ \\
\hline 7-Craft and related trades workers & $1.7 \%$ & $2.4 \%$ & $2.5 \%$ & $2.6 \%$ & $3.3 \%$ & $3.6 \%$ & $3.7 \%$ \\
\hline 8-Plant and machine operators, and assemblers & $1.2 \%$ & $1.7 \%$ & $1.9 \%$ & $2.1 \%$ & $2.2 \%$ & $3.1 \%$ & $3.1 \%$ \\
\hline 9-Elementary occupations & $0.5 \%$ & $0.8 \%$ & $0.9 \%$ & $1.3 \%$ & $1.6 \%$ & $1.9 \%$ & $2.1 \%$ \\
\hline Categories $6+7+8+9$ & $0.9 \%$ & $1.4 \%$ & $1.5 \%$ & $1.6 \%$ & $1.9 \%$ & $2.3 \%$ & $2.5 \%$ \\
\hline categories $4+5+6+7+8+9$ & $3.1 \%$ & $4.3 \%$ & $5.0 \%$ & $5.7 \%$ & $6.7 \%$ & $7.5 \%$ & $8.0 \%$ \\
\hline
\end{tabular}

Further evidence of underemployment among university graduates can be seen in Table two. We observe that the share of university graduates that are working in clerical, service and sales jobs has increased from 16\% in 2004 to $26 \%$ in 2014.

During the same interval the percent of university graduates working in all semi and low skill jobs, has increased from $21 \%$ to more than $32 \%$. In other words at least three out of every ten university graduates, in 2014, were employed in occupations that did not require university degrees. If we add the $11 \%$ unemployment rate of university graduates to this figure it reveals that in that year almost $43 \%$ of university graduates in Turkey were either unemployed or underemployed.

\begin{tabular}{|c|c|c|c|c|c|c|c|}
\hline ISCO Job Category & 2004 & 2006 & 2008 & 2010 & $2012^{*}$ & 2013 & 2014 \\
\hline 4) Clerical Support Workers & $11 \%$ & $12 \%$ & $13 \%$ & $14 \%$ & $13 \%$ & $14 \%$ & $14 \%$ \\
\hline 5) Service and Sales Workers & $5 \%$ & $6 \%$ & $7 \%$ & $8 \%$ & $11 \%$ & $12 \%$ & $12 \%$ \\
\hline Categories $4+5$ & $16 \%$ & $19 \%$ & $20 \%$ & $22 \%$ & $24 \%$ & $25 \%$ & $26 \%$ \\
\hline 6-Skilled agricultural, forestry and fishery workers & $1.3 \%$ & $1.3 \%$ & $1.2 \%$ & $1.4 \%$ & $1.2 \%$ & $1.2 \%$ & $1.3 \%$ \\
\hline 7-Craft and related trades workers & $2.2 \%$ & $2.7 \%$ & $2.4 \%$ & $2.2 \%$ & $2.4 \%$ & $2.6 \%$ & $2.7 \%$ \\
\hline 8-Plant and machine operators, and assemblers & $1.1 \%$ & $1.4 \%$ & $1.4 \%$ & $1.3 \%$ & $1.2 \%$ & $1.6 \%$ & $1.5 \%$ \\
\hline 9-Elementary occupations & $0.6 \%$ & $0.8 \%$ & $0.9 \%$ & $1.2 \%$ & $1.2 \%$ & $1.4 \%$ & $1.6 \%$ \\
\hline Categories $6+7+8+9$ & $5.1 \%$ & $6.2 \%$ & $5.9 \%$ & $6.1 \%$ & $6.1 \%$ & $6.8 \%$ & $7.0 \%$ \\
\hline Categories $4+5+6+7+8+9$ & $21.5 \%$ & $24.9 \%$ & $26.2 \%$ & $28.1 \%$ & $29.6 \%$ & $32.2 \%$ & $32.6 \%$ \\
\hline
\end{tabular}

Source of data: TurkStat, shares calculated by Authors, ${ }^{*}$ 2012-2014 data are based on the revised ISCO occupation categories.

While the 2015 data is not available, the monthly labor statistics points to an increase in unemployment rate, particularly among the youth. The rising political tensions and the ethnic conflict in southeastern part of Turkey have had an adverse effect on Turkish economy in 2015 and there is little hope that the situation will improve in the first half of 2016. It is also worth noticing that a large share of the burden of unemployment and underemployment among university graduates has fallen on the women. University enrolment has increased sharply among women in the past decade and in 2014 they accounted for 51\% of university graduates in the 20-29 years-old age category. Yet the unemployment rate among young women is 
much higher than young men. The July 2015 unemployment rate for women and men in the $15-24$ year age group was $23 \%$ and $15.6 \%$ respectively ${ }^{6}$.

\section{Causes of the Rapid Quantitative Growth in Higher Education}

The statistical image of the quantitative expansion of higher education industry in Turkey begs the question of how this rapid expansion after 2002 has come about. We argue that this expansion was a direct result of the higher education policies of the Justice and Development Party (AKP) government, which enjoyed full control over management and allocation of recourses to this sector. Turkey's universities enjoyed a large degree of autonomy in their operations before 1981. In response to the widespread political violence on university campuses during 1970s the military junta that came to power in 1980 created the National Board of Higher Education (commonly referred to by the abbreviation of its Turkish title as "YOK") to regulate the political activities of students and faculty. Overtime YOK enjoyed considerable control over operations of the institutions of higher education and was able to regulate the admissions and academic policies at the national level.

The strong public demand for university education was a well-known fact to all political parties in Turkey ever since 1970s, and during political elections it regularly appeared in their political agenda. This strong demand was demonstrated by the fact that only a small share of participants in the annual national university entrance exams were granted admission to universities every year. In 2002-03 academic year, for example, only $20.1 \%$ of the 1.82 million applicants who took the placement exam were admitted to a university ${ }^{7}$. Concern about quality and limited availability of fiscal resources, however, prevented a rapid expansion of enrollment in 1980s and 1990s. The AK Party political leaders realized the political benefits of increasing the admission capacity of universities and found a strategy that shifted a large share of the financial cost of this expansion to the private sector.

After winning the 2002 election, the AKP realized that for political reasons it had to address this strong demand for higher education. As observed by Tuzen and Yurtseven (2016), the AKP leadership calculated that if, as a governing party, it did not address the strong public demand for higher education, the rival political parties could increase their political support by including this issue in their agenda during parliamentary elections ${ }^{8}$.

To overcome the financial constraints for expansion of higher education AKP turned to neoliberal economic policies of privatization and market-oriented deregulation that were initiated two decades earlier. These economic reforms, which, were initiated by Prime Minister Turgut Ozel in 1980s, with the support and encouragement of the IMF, were also embraced by the AKP after 2002. The AK Party facilitated the expansion of the higher education by promotion of non-profit private universities and partial commercialization of public universities.

By focusing on expansion of non-profit (private) universities (commonly referred to as Foundation Universities) the AKP government was able to increase the enrollment capacity of higher education without a significant increase in the fiscal burden of higher education. Turkey's first foundation university (the Bilkent 
University) was established in 1984 and 22 more foundation universities were established by 2002 (the year that AKP came to power). During 2002 and 2016, 53 more foundation universities were created. During the same interval the number of public universities rose from 53 to 109 units. At the same time YOK allowed public universities to offer evening and tuition-based degrees (in addition to their regular services) to enhance their revenues. The combined effect of these private and public initiatives led to a large increase in total student enrollment in tertiary education.

\begin{tabular}{|c|c|c|}
\hline Academic Year & 1997-98 & 2012-13 \\
\hline Share of Higher Education in Total Education Budget & $39.50 \%$ & $32.50 \%$ \\
\hline Higher Educaiton Budget as a Share of GDP & $0.69 \%$ & $0.89 \%$ \\
\hline Higher Education Budget as a Share of Consolidated & & \\
\hline Budget & $3.18 \%$ & $3.63 \%$ \\
\hline $\begin{array}{l}\text { Share of Higher Education in the Investment Budget } \\
\text { of the Ministry of National Education (MEB) }\end{array}$ & $15.10 \%$ & $6.64 \%$ \\
\hline $\begin{array}{l}\text { Number of Students in Higher Education Institutions } \\
\text { (millions) }\end{array}$ & 1.322 & 4.937 \\
\hline
\end{tabular}

The impact of these policies on fiscal cost of higher education and student enrollment can be seen in Table 3. We can see that while the total number of students enrolled in all institutions of higher education nearly quadrupled between 1997-08 and 2012-13 academic years, the fiscal burden of government spending on higher education only modestly increased. The higher education fiscal budget as a share of Gross Domestic Product and as a share of total government budget increased modestly because the privatization and commercialization policies of the AKP government shifted a large share of the education expenses to the private sector. We can also see in Table 3 that the share of higher education in the investment budget of the Ministry of Education declined sharply between 1997-08 and 2012-13 academic years. Overall, the figures in Table 3 support the argument that neoliberal economic policies of AKP government facilitated the expansion of the higher education enrollment capacity.

An added economic benefit of this strategy of domestic capacity expansion was that it helped Turkey direct some of the students with strong financial backgrounds, who would have gone to Western countries for a university education to domestic alternatives. High quality, high tuition foundation universities, such as Bilkent University, offered an attractive domestic alternative for these types of students. As a result Turkey was able to save on the hard currency that would have been required for these students educational expenses abroad. 
Along with rapid enrollment growth in both private and public universities, the AKP government also showed a willingness to compromise on the student-faculty ratio. As noticed by a former director of YOK, İsa Eşme, the student-faculty ratio rose from 16 in 2000 to 21 in 2013 for all institutions of higher education. The student-faculty ratio in new universities that were established during 2006 and 2008 was close to 100 students per faculty, which reduced the quality of education in these universities ${ }^{9}$. According to the 2011 Global Competitiveness Report, the ranking of Turkey for the quality of higher education index declined from 57 in 2006 to 71 in $2010^{10}$.

Furthermore, many of the new universities, which did not have an adequate teaching staff and educational facilities, were established in the less developed regions of eastern Turkey. In a March 2015 speech in Turkish Parliament, Erol Dora, a parliament member from the southeastern city of Mardin, delivered a very strong criticism of the AK Party's University establishment policies in less developed provinces. He pointed to the large number of unemployed university graduates in these regions and blamed the rapid expansion of university enrollment without attention to quality or development of relevant skills for their predicament ${ }^{11}$. As an evidence of poorly equipped universities Dora mentioned the Hakkari University in Southeastern part of the country, which (according to Dora,) suffered from a severe shortage of faculty and infrastructure in 2015. To cope with this shortage many students were sent to other universities as guest students while being counted as students of Hakkari University.

The AKP also increased the size and availability of student loans to make higher education more affordable. As noted by then Prime Minister Erdoğan in 2012, the number of university students that received student loans and financial assistance increased from 452 thousand in 2002 to 1.71 million in 2012. At the same time the average monthly value of these payments rose from 42 TL to 450 TL during this interval ${ }^{12}$. Increased reliance on student loans was another strategy that allowed AKP to shift a portion of the room and board costs to the students in public universities as the enrollment was rising.

The AKP higher education policy enjoyed popular support as it satisfied the strong public demand for higher education and at the same time generated significant political rewards for the AK Party as described above. The more rapid phase of this project began in late 2006 when AK Party released a policy document titled Turkey's Higher Education Strategy ${ }^{13}$. As was explained earlier, most of the new foundation and public universities were established in or after 2006. The AK Party adopted the slogan "One University in Every City" to mobilize political support for its higher education strategy. The quantitative success of this project after 2006 is best demonstrated by the following observation:

Between 1933 and 2005 seventy seven universities were established in Turkey.

From 2006 to 2015, an additional 116 universities were established and 52 of them were foundation universities ${ }^{14}$.

By 2015 there was at least one university in each of Turkey's 81 provinces. In many towns and cities establishment of the first university was not only welcomed by young adults and their parents, but also by the local business community who viewed a university as a source of economic growth and prosperity. The regional 
and local business associations, in turn, were motivated by these incentives to lobby the government for creation of new universities in their respective communities ${ }^{15}$.

\section{Warning Signs and Policymakers Awareness about Overeducation}

As the national body responsible for planning and development of higher education, YOK has had full control over curriculum development and student enrollment in Turkey's institutions of higher education. While YOK can take credit for facilitating the rapid expansion of the enrollment capacity in tertiary education, it must also accept responsibility for the lack of coordination between the supply of university graduates and the labor market demand for graduates in specific fields of study. This disconnect has resulted in high rates of unemployment for university graduates and, as we demonstrated above, it has forced a growing number of graduates to accept jobs that do not utilize their skills.

Did YOK take the labor market demand into account when deciding the annual admission quotas of public and foundation universities for each major? The persistent oversupply of university graduates suggests that either YOK did not receive any realistic projections on labor demand or policy makers received warnings but decided to continue with the fast growth policy because of other priorities. A review of academic publications and op-ed articles shows that very few warnings and criticisms about overeducation were published in early years of AKP rule but as the unemployment and underemployment of university graduates worsened the number of warnings and criticisms increased.

One of the most important early warnings was issued by a government insider in 2008, (which was one of the peak years for establishment of new universities and expansion of enrollment). In February of that year, Turkey's minister of Industry and Trade, Zafer Çağlayan, released an open letter to the director of (YOK), Yusuf Ziya Özcan, and warned him about lack of appropriate manpower planning in YOK ${ }^{16}$. In this eight-page letter Çağlayan strongly criticized YOK for the growing unemployment crisis. He argued that there must be a close coordination between the labor market skill needs and university enrollment in each degree. He further argued that this coordination must take place both at national and regional level to make sure that new universities train an adequate labor force for their surrounding regions.

Surprisingly, Çağlayan's warning did not generate any reaction inside YOK or in the media. Indeed when we search the Turkish media articles and academic reports on higher education during 2002-2010, we find very few warnings or analysis regarding the risk of overeducation and overschooling. This is mainly because up until then the excess supply of university graduates was not at a critical level. Instead of worrying about overeducation, the main concern for policy makers and experts was the large number of university applicants that were denied admission because of limited capacity.

Even a detailed analysis of Turkey's system of higher education by a team of experts from European Union, which was released in October 2008, did not pay any attention to the potential for oversupply of graduates ${ }^{17}$. This report acknowledged the fact that unemployment rate among university graduates was already larger 
than high school graduates but attributed this gap to the low quality of higher education (and skill mismatch) rather than excess supply of qualified graduates ${ }^{18}$. As the labor market conditions for university graduates have deteriorated in recent years the number of articles in Turkish media about unemployment and underemployment crisis of university graduates have increased steadily year after year ${ }^{19}$. The warnings have come from academicians, business leaders and journalists. One of the most vocal critics of the AKP's focus on quantitative growth in higher education is the president of Middle East Technical University, Ahmed Acer ${ }^{20}$.

In 2015 two prominent Turkish business leaders, Kenan Yavuz ${ }^{21}$ and Abdülkadir Konukoğlu ${ }^{22}$, strongly criticized Turkey's system of higher education for training too many university graduates with low skills and high expectations. Yavuz called on YOK to reduce enrollment in four-year university programs and train more students in vocational skills, which, in is opinion, were more in demand.

There are some indications that the recent alarming statistics about deteriorating job market conditions for university graduates and media criticism are finally causing some universities to reduce their enrollments. The decision of Istanbul University to reduce its student enrollment in 2015-16 academic year (which was mentioned at the beginning of this Brief,) is likely to attract attention because of this university's leading role in Turkey's higher education. This reversal is important because it must have happened with the approval of YOK. In a similar development in 2015, the YOK director announced higher quality standards for the medicine and law schools to assure that graduates will have the required skills for these sensitive jobs. This focus on quality will result in a reduction of annual student admissions. He further announced that these higher standards would be gradually applied to other university programs as well ${ }^{23}$.

At the same time some universities are experiencing excess capacity because potential students are becoming more mindful of the high unemployment among graduates. Low enrollment has affected many majors in several universities and in 2011 YOK responded to this situation by calling on these universities to consolidate the degrees and departments that did not have adequate enrollment ${ }^{24}$. More recently, in summer 2015 YOK announced that it would not allow public universities to maintain a department unless at least 11 students were enrolled ${ }^{25}$. This was a response to the steady decline in the number of students majoring in some basic science programs such as mathematics, physics and chemistry during 2010-2014 academic years. Fearing lack of jobs for these majors many students have switched to business, economics, computer programming and engineering in these years ${ }^{26}$.

\section{Conclusion:}

There is strong evidence that the rapid increase in capacity of institutions of higher education in Turkey was driven by two important factors: First, the APK realized that expansion of higher education opportunities was a highly popular policy that would increase its popularity among a large segment of Turkish society, particularly among the lower and middle classes. Second, by relying on privatization of higher education and promotion of foundation universities AKP found a way to expand the higher education sector without a significant increase in 
its fiscal burden. Furthermore, since government was willing to relax the quality standards a rapid growth was achieved within a short period of time.

In the early years of this policy of quantitative expansion there was little concern or warning about the risk of excess supply of university graduates. It is only since 2010 that the rising unemployment and underemployment among university graduates has attracted media attention. With the large enrollment capacity of new universities, getting admission into higher education is no longer a major social concern and hence it will no longer have any political value as an election promise for the AKP or the opposition parties. Instead, the public concern is gradually shifting to the job market condition for university graduates and this issue is likely to become more politicized in the years ahead.

In general university education is likely to remain highly popular in Turkey and it is unlikely that any political party will call for linking the admission quotas for each major to labor demand projections that are determined by a comprehensive manpower planning mechanism ${ }^{27}$. Instead, we are likely to witness partial and selective rollbacks in programs that are experiencing higher rates of graduate unemployment. Furthermore, as the public become more aware of the poor job market prospects for a major, the university applicants are likely to shy away from that major and become highly selective in their choice of major and university. This is already causing excess capacity in some majors and this trend is likely to continue in the coming years.

The rise of overeducation in Turkey is not a unique experience. Many developed and developing countries have ended up in a similar situation in the past two decades. In Europe and the United States an average of 20 to 30 percent of the young adults are overeducated for their jobs. The Middle Eastern country with the most similar experience to Turkey in the higher education sector is Iran. The higher education policies of Iran under President Mahmoud Ahmadinejad (2005-12) were remarkably similar to Turkey under AKP in the same period. In recent years Iran has experienced a more severe case of overeducation than Turkey ${ }^{28}$.

${ }^{1}$ http://www.isilanlarim.net/istanbul-universitesi-ogrenci-alma-kontenjaninidusurecek/

2 http://www.noktadergisi.info/ekonomi/issizlik-en-cok-universite-mezunlarindaartiyor-h3218.html , July 17, 2016 (Last cited, January 5, 2016). 3 http://www.zaman.com.tr/ekonomi 1-milyon-issiz-universite-mezunuvar 2319611.html, October 2, 2015 (Last cited, February 1, 2016).

${ }^{4}$ Higher Education Board of Turkey (Yüksek Öğretim Kurumu) (YÖK) (2007). “Türkiye'nin Yüksek Öğretim Stratejisi.”(Higher Education Strategy for Turkey) Ankara,Yüksek Öğretim Kurumu. 
5 Job Markets in Turkey Face a Tsunami of University Graduates, May 15, 2015, University World News, http://www.universityworldnews.com/article.php?story=20150513112900292

6 "Labor Force Statistics, July 2015", Turkish Statistics Institute, http://www.turkstat.gov.tr/HbGetirHTML.do?id=18642, October 15, 2015.

7 Source: OSYM (Turkey Student Selection and Placement Center) http://osym.gov.tr.

${ }^{8}$ Tuzen, Z. and Yurtseven, C. (2016) The Transformation of the Higher Education System in Turkey after 2002: A Game Theoretic Analysis. Theoretical Economics Letters, 6, 97-105. http://dx.doi.org/10.4236/tel.2016.61012

${ }^{9}$ http://www.aljazeera.com.tr/gorus/turk-universitelerinin-egitim-ogretim-vearastirma-performanslari

${ }^{10}$ http://www.haberturk.com/yazarlar/pervin-kaplan/556157-yuksekogretimdebuyume-var-gelisme-yok

11 The text of Erol Dora's address to the parliament (in Turkish) on March 31, 2015 can be found in the following link:

https://www.tbmm.gov.tr/develop/owa/genel kurul.cl getir?pEid=39743. (Cited on February 10, 2016.

12 http://www.akparti.org.tr/site/haberler/universite-sayisini-168eulastirdik/33112\#1 (Cited on February 15, 2016)

13 See endnote 1.

${ }^{14}$ Annual growth in number of universities is demonstrated in slide 10 of the following file: http://www.slideshare.net/YamurKaya/her-le-bir-niversite-politikas

${ }^{15}$ Arap, Sultan Kavili, Türkiye Yeni Üniversitelerine Kavuşurken: Türkiye'de Yeni Üniversiteler ve Kuruluş Gerekçeleri,Ankara Üniversitesi SBF Dergisi 65-1 , http://dergiler.ankara.edu.tr/dergiler/42/1346/15599.pdf

16 “Bakan'dan YÖK'e 'işsiz bırakan bölüme öğrenci almayın' mektubu”, Hurriyet, February 9, 2008, http://www.hurriyet.com.tr/bakan-dan-yok-e-issiz-birakanbolume-ogrenci-almayin-mektubu-8196267, (Last cited, February 22, 2016).

17 Visakorpi, Jarmo, Fuada Stankovic, Julio Pedrosa, Christina Rozsnyai "Higher Education in Turkey: Trends, Challenges, Opportunities", European University Association, October 2008.

18 Ibid, page 12.

${ }^{19}$ Some of these warnings and evidence of the overeducation crisis in Turkey can be found in the Turkish page of the following website: www.overeducation.org. 
${ }^{20}$ http://www.haberturk.com/yazarlar/pervin-kaplan/556157-yuksekogretimdebuyume-var-gelisme-yok

${ }^{21}$ http://t24.com.tr/haber/socar-ceosundan-gencleri-uzecek-tweetler,302339

${ }^{22}$ http://www.yenisoz.com.tr/patronlar-isyanda-haber-2108

${ }^{23} \mathrm{http://www.osym2016.com/node/869}$

${ }^{24}$ http://www.hurriyetdailynews.com/default.aspx?pageid=438\&n=universitydepartments-lack-pupils-face-closure-2011-08-25

25 http://www.hurriyet.com.tr/yok-kapatip-guclendirecegiz-akademisyenler-bilimbiter-28865916

26 ibid.

27 One of the necessary steps for addressing this issue is to link the annual enrollment in each university program to the projected job market demand for that specialty. However, applying this type of manpower planning to higher education will result in low admission rates for many degrees and limiting access to higher education might not be politically feasible.

28 "Iran's Crisis of Overeducation: Causes and Ramifications", Middle East policy Brief Series, Crown Center for Middle East Studies, February 2015, No. 89.

http://www.brandeis.edu/crown/publications/meb/meb89.html 